\title{
Evidence for cross-infection in an outbreak of Clostridium difficile-associated diarrhoea in a surgical unit
}

\author{
G. P. TESTORE, "A. PANTOSTI, *M. CERQUeTtI, S. BABUDIERI, G. PANICHI and \\ *P. MASTRANTONIO GIANFRILLI
}

III Clinica Medica, Università degli Studi di Roma, "La Sapienza", Viale Università 37, and "Laboratorio di
Batteriologia e Micologia Medica, Istituto Superiore di Sanità, Viale Regina Elena 299, Roma

Summary. Environmental studies were performed in a hospital outbreak of Clostridium difficile-associated diarrhoea. Transmission was associated with the sluice room and the storage room where medical equipment was found to be contaminated with C.difficile. Typing of isolates by antibiotic-susceptibility patterns and profiles of EDTA-extracted proteins showed the presence of an "epidemic" strain common to the majority of patients and environmental sites. Control of the outbreak was achieved by improvement of environmental hygiene and use of disposable equipment.

\section{Introduction}

The epidemiology of Clostridium difficile-associated diarrhoea has not yet been fully clarified. Several studies have reported that the environment may be a source of infection (Mulligan et al., 1980; Fekety et al., 1981; Kim et al., 1983; Hall et al., 1985; Cumming et al., 1986). More information about the epidemiology of C.difficile infection can be acquired only if a typing system is used.

We studied the circulation of C.difficile in a surgical unit where, in a six week period, 10 patients experienced $C$.difficile-associated diarrhoea. Stools from hospital staff and environmental samples were cultured for $C$.difficile and typing procedures were performed on the isolates.

\section{Materials and methods}

\section{Patients}

Patients were deemed to be affected by C.difficileassociated diarrhoea if they had three or more bowel movements with liquid faeces per day and had received antimicrobials, and if $C$.difficile was isolated from cultures of their faeces. The presence of faecal $C$.difficile cytotoxin was determined by conventional techniques (Chang et al., 1979).

\section{Environmental studies}

Environmental cultures (150 samples) were obtained from patient-related zones, the nurses room, the sluice

Received 21 April 1987; revised version accepted 7 Sep. 1987. room and adjoining storage room and equipment therein. Samples were obtained by swabbing an area roughly $10 \mathrm{~cm}$ in diameter with sterile cotton-tipped swabs, previously moistened with sterile saline $(0.85 \% \mathrm{NaCl})$. A CCFA plate (George et al., 1979) was then inoculated with the swab. Plates were incubated at $37^{\circ} \mathrm{C}$ in an anaerobic chamber for $48-72 \mathrm{~h}$ before examination and for up to 5 days before being discarded.

Samples were also obtained from the fingers of the only nurse who was attending patients during the environmental study. Stool samples were obtained from all 35 staff members and nine patients who did not have diarrhoea for culture for C.difficile.

\section{Typing of isolates}

Isolates were typed on the basis of (1) antibiotic susceptibility patterns by the agar dilution method (Sutter et al., 1980) with chloramphenicol, clindamycin, tetracycline, erythromycin and rifampicin, and (2) profiles of EDTA-extracted surface proteins obtained by sodium dodecyl sulphate-polyacrylamide gel electrophoresis (SDS-PAGE). The method of SDS-PAGE was slightly modified from that of Poxton et al. (1984). Briefly, strains were grown overnight in PPY broth (Holbrook et al., 1977); the washed pellets were extracted with $10 \mathrm{mM}$ EDTA at $45^{\circ} \mathrm{C}$ for $30 \mathrm{~min}$; proteins $(c .100 \mu \mathrm{g}$ as measured by the method of Lowry et al., 1951), were separated in $10 \%$ slab gels at constant current; mol. wt markers (BioRad) were included in electrophoresis runs. Gels were then stained with Coomassie blue, photographed and dried in a gel drier.

\section{Results}

Ten patients had C.difficile-associated diarrhoea; all were women admitted to the same surgical unit. 
Table I. Clinical data of patients with C.difficile-associated diarrhoea

\begin{tabular}{|c|c|c|c|c|}
\hline $\begin{array}{l}\text { Patient } \\
\text { no. }\end{array}$ & Age & $\begin{array}{l}\text { Surgical } \\
\text { operation }\end{array}$ & Antibiotic & $\begin{array}{l}\text { Result of test for } \\
\text { faecal cytotoxin }\end{array}$ \\
\hline 1 & 52 & cholecystectomy & clindamiçin & n.t. \\
\hline 2 & 51 & cholecystectomy & ampicillin & n.t. \\
\hline 3 & 54 & cholecystectomy & ceftriaxone & + \\
\hline 4 & 40 & cholecystectomy & clindamicin & n.t. \\
\hline 5 & 85 & colon carcinoma & ampicillin & - \\
\hline 6 & 23 & pelvic inflammatory disease & cefotaxime & + \\
\hline 7 & 53 & intestinal obstruction & cefotaxime & + \\
\hline 8 & 66 & metastatic carcinoma & cefoxitin & + \\
\hline 9 & 32 & cholecystectomy & clindamicin & + \\
\hline 10 & 86 & cholecystectomy & ceftriaxone & + \\
\hline
\end{tabular}

n.t. $=$ Not tested

Table I shows the clinical data of these patients. Their ages were in the range $23-86$ years (mean 54 ). All but two patients (nos. 6 and 8) underwent abdominal surgery, and used bed-pans and had rectal tubes in situ during the first and second days after surgery. Antimicrobial prophylaxis was started on the day of operation; patients nos. 6 and 8 received antibiotics on the day of admission. Three patients received clindamycin, two patients ampicillin, two patients ceftriaxone, two cefotaxime and one patient cefoxitin. Intervals between the first antibiotic dose and the start of diarrhoea

Table II. Distribution of $C$. difficile in the environment

\begin{tabular}{ll}
\hline Sites examined & Number positive/number sampled \\
\hline Case-related zones & \\
Floors & $0 / 50$ \\
Walls & $0 / 10$ \\
Bedlinen (in use) & $0 / 20$ \\
Bedside tables & $0 / 10$ \\
Chairs, benches & $0 / 10$ \\
Nurses room & \\
Floor & $0 / 1$ \\
Furniture & $0 / 7$ \\
File & $0 / 2$ \\
Wash-basin & $0 / 1$ \\
Trolleys & $0 / 3$ \\
Sluice room & \\
Floor & $3 / 3$ \\
Sluice & $2 / 2$ \\
Bedpans (used) & $4 / 5$ \\
Chamberpots (used) & $3 / 5$ \\
Washing water & $1 / 1$ \\
Shelves & $1 / 4$ \\
Storage room & $3 / 3$ \\
Floor & $2 / 5$ \\
Bedpans (clean) & $2 / 6$ \\
Rectal tubes (clean) & $0 / 2$ \\
Equipment for enema & \\
\hline
\end{tabular}

were 2-5 days. Faecal cytotoxin assays were done on samples from seven patients and toxin was detected in six. In all patients, symptoms subsided promptly with vancomycin treatment $(250 \mathrm{mg}$ four times daily for 5 days).

All environmental samples from patient-related zones and the nurses room gave negative results in cultures for C.difficile. The majority of samples obtained from the environment and from items in the sluice room and in the storage room gave positive cultures for $C$.difficile with the exception of the equipment for administering enemas (table II). Samples from the hands of the nurse gave positive cultures for C.difficile. Cultures of faecal samples

Table III. Results of typing C.difficile isolates

\begin{tabular}{llc}
\hline Strains tested & $\begin{array}{c}\text { Antibiotic } \\
\text { susceptibility }\end{array}$ & $\begin{array}{c}\text { Electrophoretic } \\
\text { type }\end{array}$ \\
\hline Patient & & \\
1 & $\mathbf{R}$ & II \\
2 & $\mathrm{R}$ & II \\
3 & $\mathrm{R}$ & II \\
4 & $\mathrm{R}$ & II \\
5 & $\mathrm{R}$ & II \\
6 & $\mathrm{R}$ & II \\
7 & $\mathbf{R}$ & II \\
8 & $\mathbf{R}$ & II \\
9 & $\mathrm{~S}$ & VII \\
10 & $\mathbf{R}$ & I \\
Environment & & \\
sluice & $\mathbf{R}$ & II \\
floor of sluice room & $\mathbf{R}$ & II \\
chamber pots & $\mathbf{R}$ & II \\
rectal tubes & $\mathbf{R}$ & II \\
bedpans & S & VII \\
bedpan washing water & $\mathbf{R}$ & I \\
Hands of nurse & $\mathbf{R}$ & II \\
& & \\
\hline
\end{tabular}

$\mathbf{R}=$ resistant to the antibiotics tested.

$\mathrm{S}=$ susceptible to the antibiotics tested. 


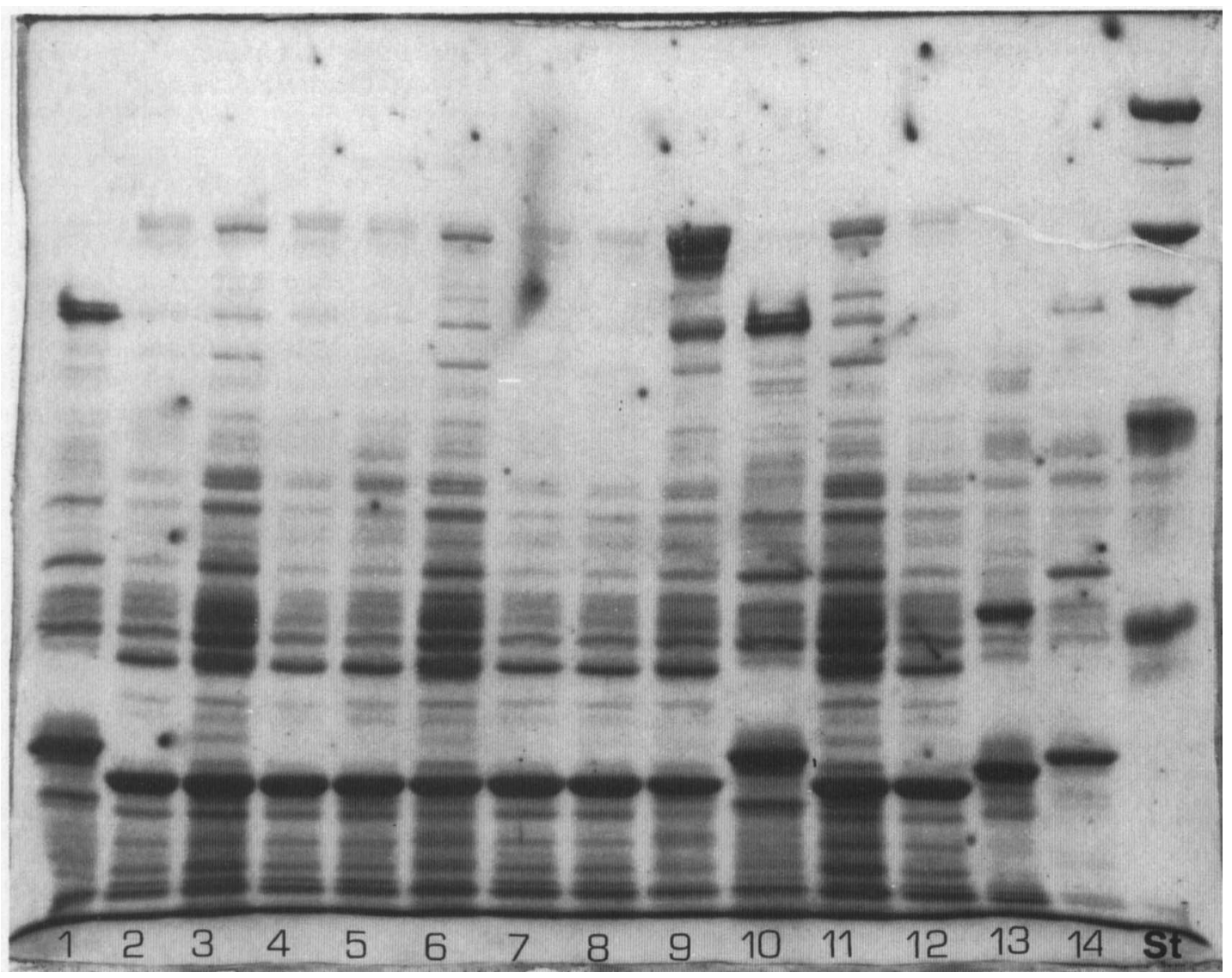

Figure. SDS-PAGE of EDTA-extracted proteins from C.difficile strains isolated during the outbreak. Tracks 2-8 and 11-12: strains of the "epidemic" type (type II) isolated form patients and environment. Tracks 1,9,10,13 and 14: strains with different profilestype VII (tracks 1,10,14), type I (track 9). Track 13 is a strain from a patient in a different ward. Tracks 1 and 10 represent duplicates of the same strain. S.T. $=$ mol. wt standards $($ Bio-Rad $)$.

from staff and from the nine patients without diarrhoea were negative for $C$.difficile.

The typing systems employed showed that the majority of isolates from patients and the environment had identical antibiotic susceptibility patterns (strains were resistant to all the antibiotics tested) and the same electrophoretic protein profile (figure), a pattern defined in previous studies as type II (Pantosti et al., 1986). Strains with different patterns (type I and type VII) were isolated from two patients and two environmental specimens (table III).

\section{Discussion}

It has not yet been fully clarified whether C.difficile-associated diarrhoea is an endogenous disease, implying overgrowth of the organism in a susceptible host, or an exogenous infection, or can be either.
Animal studies (Larson et al., 1980; Toshniwal et al., 1981) and investigations of hospital outbreaks (Mulligan et al., 1980; Fekety et al., 1981; Kim et al., 1983; Hall et al., 1985; Cumming et al., 1986) suggest that $C$.difficile can be acquired from the environment. Recently, typing schemes for C.difficile have been applied to epidemiological studies of outbreaks of diarrhoea caused by this organism (Delmee et al., 1986; Heard et al., 1986).

We observed a cluster of $C$.difficile-associated diarrhoea in a surgical unit and the contamination of the environment with the same micro-organism. By SDS-PAGE we were able to recognise a protein pattern common to the majority of the strains isolated from patients and the environment; only four strains had different protein profiles. If unselected $C$.difficile strains from various sources are examined, several different patterns can be obtained by this method (Pantosti et al., 1986). Therefore, our results suggest the circulation of the 
same "epidemic" strain in the hospital ward. The protein pattern of this strain was identified as type II.

By antibiotic susceptibility testing only two strains could be identified as different from the "epidemic" resistant strains: the usefulness of this method is limited by the relatively uniform susceptibility-pattern of $C$.difficile strains to antibiotics (Gianfrilli et al., 1984).

We did not find C.difficile in the areas of patient beds but we isolated it from the hands of the nurse who attended the patients, from the sluice room and dirty items, and from clean medical equipment kept in the storage room. It is likely, therefore, that spread of infection among the patients occurred via the hands of the nurse and the contaminated fomites.

\section{REFERENCES}

Chang T W, Lauermann M, Bartlett J G 1979 Cytotoxicity assay in antibiotic-associated colitis. Journal of Infectious Diseases 140: 765-770.

Cumming A D, Thomson B J, Sharp J, Poxton I R, Fraser A G 1986 Diarrhoea due to Clostridium difficile associated with antibiotic treatment in patients receiving dialysis: the role of cross infection. British Medical Journal 292: 238-239.

Delmee M, Bulliard G, Simon G 1986 Application of a technique for serogrouping Clostridium difficile in an outbreak of antibiotic-associated diarrhoea. Journal of Infection 13: 59.

Fekety R, Kim K H, Brown D, Batts D H, Cudmore M, Silva J 1981 Epidemiology of antibiotic-associated colitis; isolation of Clostridium difficile from the hospital environment. American Journal of Medicine 70: 906-908.

George W L, Sutter V L, Citron D, Finegold S M 1979 Selective and differential medium for isolation of Clostridium difficile. Journal of Clinical Microbiology 9: 214-219.

Gianfrilli P, Luzzi I, Pantosti A, Occhionero M 1984 In-vitro susceptibility of Clostridium difficile isolates to 12 antimicrobial agents. Chemioterapia 3 : 41-44.

Hall S M, Calver G P, Williams M 1985 A hospital outbreak of Clostridium difficile? Journal of Hospital Infection 6: 312322.

Heard S R, O'Farrel S, Holland D, Crook S, Barnett M J, Tabaqchali S 1986 The epidemiology of Clostridium difficile with use of a typing scheme. Nosocomial acquisition and cross-infection among immunocompromised patients. Journal of Infectious Diseases 153: 159-162.

Holbrook W P, Duerden B I, Deacon A G 1977 The classification
All patients involved in this hospital outbreak had one or more risk factors for developing C.difficile-associate diarrhoea-age, previous antimicrobial therapy and abdominal surgery, all factors known to alter the bowel flora.

The number of new cases of $C$.difficile-associated diarrhoea gradually diminished after the contaminated rooms were thoroughly cleaned with sporicidal disinfectant (glutaraldehyde), disposable equipment was used whenever possible, and frequent and effective hand washing was encouraged. No isolation of patients was instituted, in contrast to reports in other C.difficile outbreaks (Heard et al., 1986). These simple measures appeared sufficient to control the spread of C.difficile in the hospital ward and, therefore, their routine application could prevent similar episodes.

of Bacteroides melaninogenicus and related species. Journal of Applied Bacteriology 42: 259-273.

Kim K, Dupont H L, Pickering L K 1983 Outbreaks of diarrhea associated with Clostridium difficile and its toxin in day-care centers: evidence of person-to-person spread. Journal of Pediatrics 102: 376-382.

Larson H E, Price A B, Borriello S P 1980 Epidemiology of experimental enterocolitis due to Clostridium difficile. Journal of Infectious Diseases 142: 408-413.

Lowry O H, Rosebrough N J, Farr A L, Randall R J 1951 Protein measurement with the folin phenol reagent. Journal of Biological Chemistry 193: 265-275.

Mulligan M E, George W L, Rolfe R D, Finegold S M 1980 Epidemiological aspects of Clostridium difficile-induced diarrhea and colitis. American Journal of Clinicial Nutrition 33: 2533-2538.

Pantosti A, Cerquetti M, Gianfrilli P M 1986 Outbreaks of C.difficile diarrhoea in hospitalised patients: demonstration of cross-infection by PAGE. XIV International Congress of Microbiology, abstract PG5-34.

Poxton I R, Aronsson B, Mollby R, Nord C E, Collee J G 1984 Immunochemical fingerprinting of Clostridium difficile strains isolated from an outbreak of antibiotic-associated colitis and diarrhoea. Journal of Medical Microbiology 17: 317-324.

Sutter V L, Citron D M, Finegold S M 1980 Wadsworth anaerobic bacteriology manual, 3rd edn. The C.V. Mosby Company, St Louis, MO, USA.

Toshniwal R, Silva J, Fekety R, Kim K H 1981 Studies on the epidemiology of colitis due to Clostridium difficile in hamsters. Journal of Infectious Diseases 143: 51-54. 